\title{
MENGGUNAKAN MASKER DAN HAND SANITIZER EFEKTIF MENCEGAH PENYEBARAN COVID-19 DI LINGKUNGAN KANTOR DESA PASIRKAMUNING
}

\author{
Lia Fikayuniar $^{1}{ }^{*}$, Oviligiar Sugiharto $^{2}$, Erliana Sari Ika Wahyuni ${ }^{3}$ \\ Universitas Buana Perjuangan Karawang \\ Program Studi Farmasi, Fakultas Farmasi, Universitas Buana Perjuangan \\ Karawang \\ Penulis Koresponding* : lia.fikayuniar@ubpkarawang.ac.id
}

\begin{abstract}
Abstrak
Pengabdian kepada masyarakat ini bertujuan untuk melaksanakan salah satu bagian dari Tri Dharma Perguruan Tinggi, memberikan edukasi mengenai "Menggunakan Masker Dan Hand Sanitizer Efektif Mencegah Penyebaran Covid-19 Di Lingkungan Kantor Desa Pasirkamuning”. Metode yang dilakukan pada kegiatan pengabdian kepada masyarat adalah melakukan edukasi melalui spanduk pencegahan Covid-19, Pemberian sejumlah masker, hand sanitizer, Tempat mencuci tangan portable lengkap beserta sabun. Hasil Kegiatan Pengabdian Kepada Masyarakat. Kegiatan pengabdian kepada masyarakat sangat sejalan dengan cara-cara yang telah di atur dengan mutlak pada peraturan ST/868/III/KEP./2020 tentang Antisipasi Virus Covid-19, dapat mencegah ada nya kasus reaktif Covid-19 di lingkungan kantor Desa Pasirkamuning dan di lingkungan masyarakat Desa Pasirkamuning.
\end{abstract}

Kata kunci : Pengabdian, Masyarakat, Masker, Hand Sanitizer, Covid-19

\begin{abstract}
This community service aims to carry out one part of the Tri Dharma of Higher Education, providing education on "Used Masks and Hand Sanitizers Effective to Prevent the Spread of Covid-19 in the Pasirkamuning Village Office Environment". The method used in community service activities is to provide education through Covid-19 prevention banners, giving several masks, hand sanitizers, complete portable hand washing places along with soap. Result in Community Service Activities. Community service activities are very much in line with the methods that have been regulating in the ST / 868 / III / KEP / 2020 regulation concerning Anticipation of the Covid-19 Virus, which can prevent reactive cases of Covid-19 in the Pasirkamuning Village office and the community of Pasirkamuning Village.
\end{abstract}

Keywords: Community Service, Mask, Hand Sanitizer, Covid-19 


\section{PENDAHULUAN}

Desa Pasirkamuning merupakan salah satu desa yang terletak di Kecamatan Telagasari Kabupaten Karawang dan berbatasan dengan kecamatan Tempuran. Desa ini mempunyai jenis potensi yaitu petani, dimana rata-rata sebagian masyarakatnya yaitu "Buruh Tani", dan hal ini dapat berpengaruh bagi kelangsungan pembangunan dan perkembangan desa tersebut. Selain itu hal yang dapat berpengaruh saat ini juga yaitu Sumber Daya Manusia.

Pada tahun 2015 Desa Pasirkamuning merupakan desa yang tertinggal, namun berjalannya waktu saat ini Desa Pasir Kamuning dapat meningkat dengan perkembangan yang cukup baik dari yang sebelumnya dalam pembangunan desa. Dengan penambahan bangunan infrastruktur salah satu nya gedung serbaguna untuk pelaksanaan pelayanan kesehatan seperti kegiatan posyandu, dan tentunya sumber daya manusia yang dijaga pula kesehatannya dengan diwajibkan menggunakan masker ketika berada di lingkungan kantor desa, pada masa pandemi Covid-19, untuk mengurangi penyebaran wabah virus tersebut.
Pada akhir tahun 2019, dunia diisukan dan digemparkan dengan mewabah-nya suatu virus yang terdengar asing ditelinga yaitu Coronavirus (SARSCov-2) dan penyakitnya sendiri disebut dengan Coronavirus disease 2019 (Covid-19), dan virus ini diketahui pada mulanya berasal dari Wuhan, Tiongkok akhir bulan Desember 2019. Dan pada saat itu sudah dipastikan terdapat 65 negara yang telah ikut terjangkit oleh virus tersebut (Data WHO, 1 Maret 2020) (PDPI, 2020). Dengan transmisi virus ini melalui manusia-kemanusia yaitu bisa melalui udara. Dengan kasus yang terjadi di Indonesi berawal dari suatu acara di Jakarata, pada penderita kontak dengan seorang warga asing asal jepang yang tinggal di malaysia, setelah ada pertemuan tersebut penderita mengeluh demam, batuk, dan sesak napas (WHO, 2020).

Partisipasi dari masyarakat yang sehat, sejahtera, dan bahagia dalam pembangunan desa tersebut sangat diperlukan. Sehingga dapat dikatakan tanpa ada-nya partisipasi dan dukungan aktif dari masyarakat terkait sebagai petugas kantor desa sebagai sumber daya manusia yang ungul dan sehat dalam pelaksaan program-program kerja desa, maka tidak akan menjadi desa yang berkembang dan sejahtera. 
Terlebih lagi dalam masa-masa pandemi Covid-19 ini, bahwa kesehatan sumber daya manusia terkait sangat harus dijaga dengan upaya-upaya pencegahan yang nyata dan sederhana, yaitu seperti menggunaikan masker, handsanitizer, mencuci tangan, jaga jarak, dan tidak disarankan bekerja jika dirasa sakit, makan-makanan bergizi, dan istirahat yang (Spripim Polri, 2020).

Tujuan pengabdian kepada masyarakat ini adalah salah satu bagian dari Tri Dharma Perguruan Tinggi, dan memberikan edukasi mengenai "Menggunakan Masker Dan Hand Sanitizer Efektif Mencegah Penyebaran Covid-19 Di Lingkungan Kantor Desa Pasirkamuning" melalui pemberian masker, handsaniter, tempat mencuci tangan portable lengkap dengan sabun, dan spanduk yang berisi poin-poin pencegahan penyebaran Covid-19.

\section{METODE}

\section{Metode}

Metode yang dilakukan pada kegiatan pengabdian kepada masyarat adalah melakukan edukasi melalui spanduk pencegahan Covid-19, Pemberian sejumlah masker, hand sanitizer, Tempat mencuci tangan portable lengkap beserta sabun.
2. Peserta

Kegiatan ini diikuti oleh 13 mahasiswa KKN Desa Pasir Kamuning, 1 Dosen pembimbing lapangan sebagai nara sumber (Pembimbing KKN), Petugas kantor (Aparat) Desa Pasirkamuning,

3. Penyelesaian masalah

Dengan ada nya permasalahan pnyebaran wabah Covid-19, maka perlu adanya jalan keluar dengan cara pemberian perlengkapan sederhana untuk pencegahan penyebaran Covid19, dan mengedukasi lewat spanduk yang berisikan point-point penting pencegahan penyebaran Covid-19 baik untuk lingkungan kantor Desa Pasirkamuning, Maupun Umum nya untuk Lingkungan Masyarakat Desa Tersebut.

4. Hasil Kegiatan Pengabdian Kepada Masyarakat.

Kegiatan pengabdian kepada masyarakat mengenai "Menggunakan Masker Dan Hand Sanitizer Efektif Mencegah Penyebaran Covid-19 Di Lingkungan Kantor Desa Pasirkamuning" sangat sejalan dengan cara-cara yang telah di atur dengan mutlak dengan peraturan pencegahan Covid-19. 
HASIL DAN PEMBAHASAN

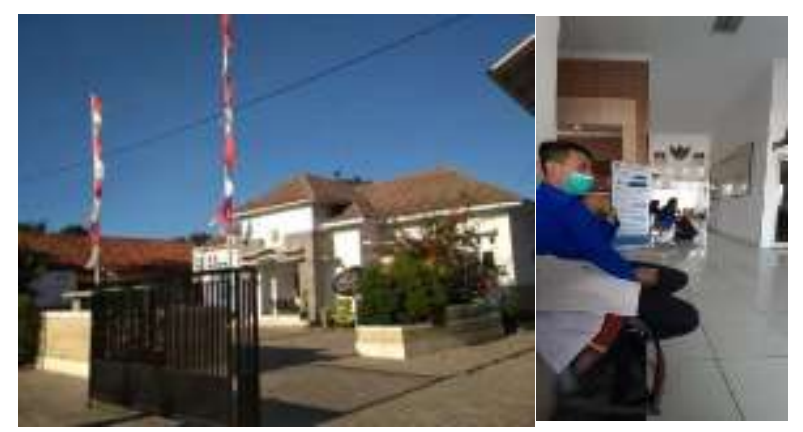

\section{Gambar 1. Kantor Desa Pasirkamuning}

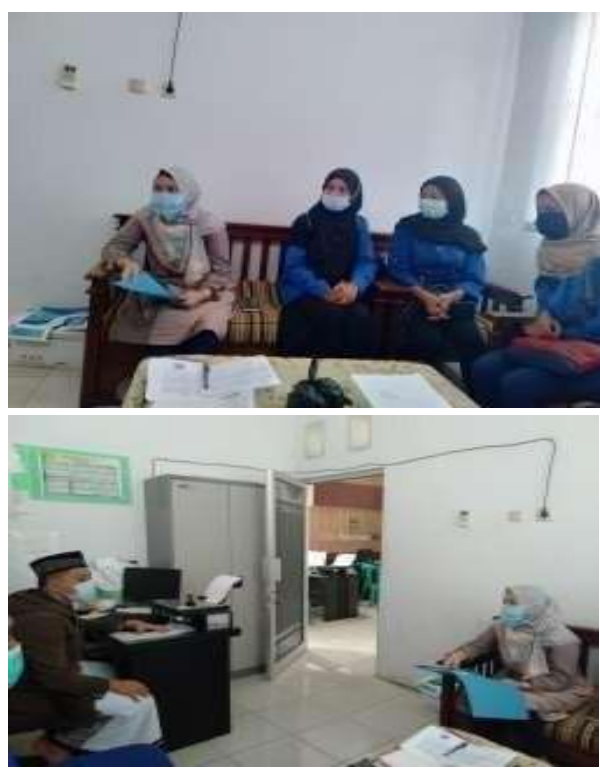

Gambar 2. Pertemuan bersama Sekdes Desa Pasirkamuning

Desa Pasirkamuning dari segi kesehatan sudah sangat baik, dapat dilihat keberadaan posyandu untuk memenuhi kesehatan masyarakat desa dengan memiliki 5 posyandu dan diadakan satu bulan sekali untuk pemeriksaan rutin posyandu anak dan 3 bulan sekali untuk pemeriksaan rutin posyandu ibu hamil. Serta Desa Pasirkamuning sudah tidak ada mandi cuci kakus (MCK), masyarakat desa pasirkamuning sudah memiliki kesejahteraan yang baik walau belum merata dan setiap rumah sudah memiliki toilet pribadi. Dalam seluruh kegiatan ini perlu dilakukan dengan menggunakan masker dan handsanitizer agar dapat mencegah penyebaran Covid-19.

Pada Gambar 1. menunjukkan bahwa kantor Desa Pasirkamuning begitu terawat dari segi kebersihan, bahkan keika memasuki ruangan kantor Desa Pasirkamuning dengan melepas alas kaki hingga terjaga kebersihan lantai kantor dari kotoran yang terbawa oleh alas kaki yang digunakan dari perjalanan, begitu juga pada Gambar 2. Menunjukkan pada lingkungan kantor Desa Pasirkamuning ini ketika pelaksanaan kegiatan kantor telah sejalan dengan protokol kesehatan pencegahan penyebaran Covid-19, yaitu menggunakan Masker dan menjaga Jarak. 


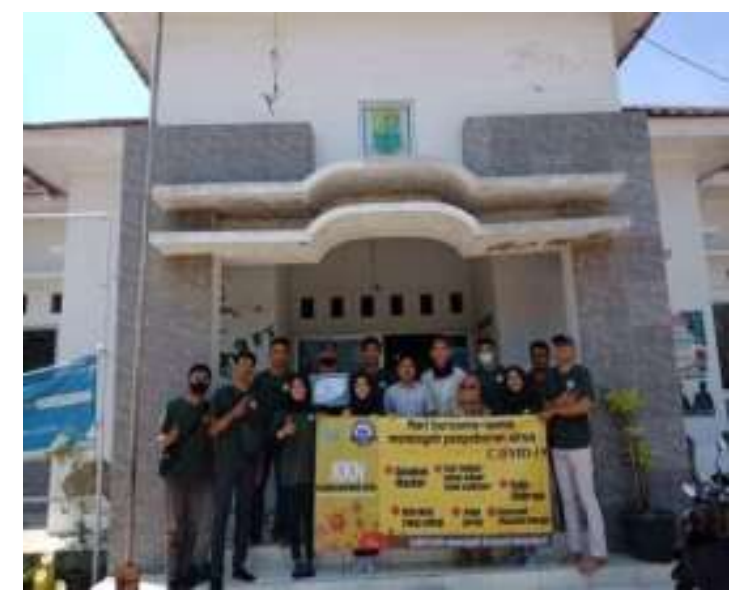

\section{Gambar 3. Pemberian Spanduk Pencegahan Covid- 19}

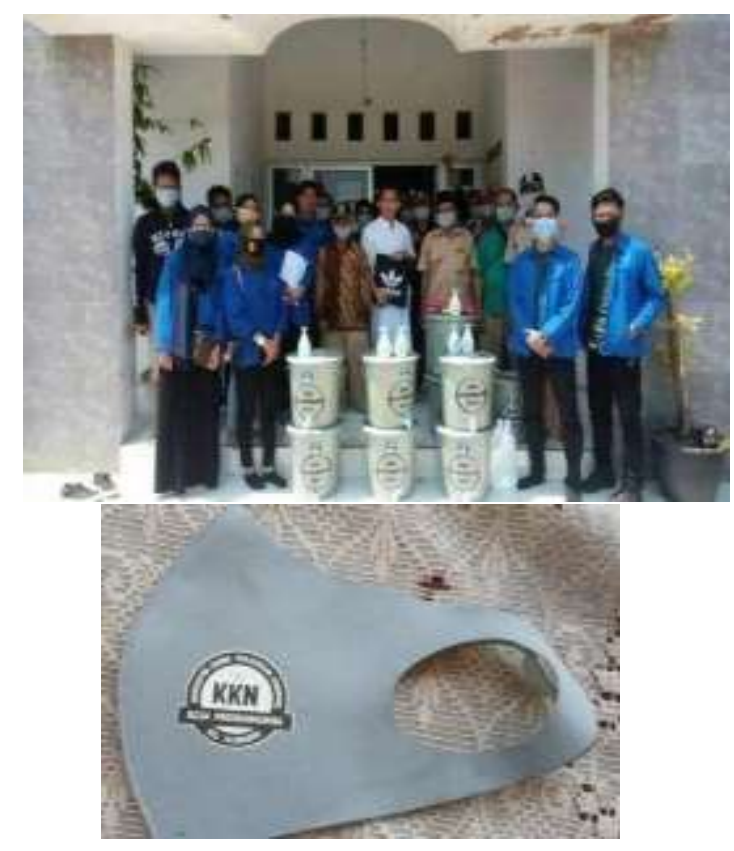

Gambar 4. Pemberian tempat cuci tangan portable beserta sabun, handsanitizer, dan masker yang di bagikan ke aparat desa untuk kembali di bagikan di setiap RT yang ada di Desa Pasirkamuning

Keterbatasan pengabdian kepada masyarakat yang telah terlaksana adalah mengedukasi menjadi tidak optimal dikarenakan tidak ada adanya penyuluhan secara langsung dengan patuh mengikuti aturan-aturan pencegahan penyebaran Covid-19, sehingga hanya dapat dilakukan edukasi melalui pemberian spanduk berisi caracara sederhana pencegahan penyebaran Covid-19 dengan pemberian perlengkapan seperti masker, hand sanitizer, tempat cuci tangan portable beserta sabun kepada lingkungan kantor Desa Pasirkamuning, dan kepada lingkungan Masyarakat Desa Pasirkamuning, yang sejalan dengan Peraturan ST/868/III/KEP./2020 tentang Antisipasi Virus Covid-19, yaitu mengatur tentang kegiatan pendukung program menjaga kesehatan tubuh (menggunakan masker, hand sanitizer, dan protap bersalaman) yang ditunjukkan pada Gambar 3. dan Gambar 4. (Spripim Polri, 2020), Sehingga dengan membiasakan menjalankan hal tersebut sampai saat ini dapat mencegah kasus reaktif di lingkungan kantor Desa Pasirkamuning dan di lingkungan masyarakat Desa Pasirkamuning.

\section{KESIMPULAN DAN SARAN}

\section{a. Kesimpulan}

I. Partisipasi masyarakat sangat diperlukan dalam upaya pembangunan sebuah desa tanpa 
adanya partisipasi tersebut desa tidak akan menjadi desa yang berkembang, sehingga dapat dikatakan desa tersebut mengalami ketidak sejahteraan dalam masyarakat dan lingkungan desa tersebut.

II. Salah Satu nya cara mendukung dilakukan nya secara nyata Protokol kesehatan pencegahan penyebaran Covid-19 baik dilingkungan kantor Desa dan di lingkungan masyarakat Desa Pasirkamuning, minimal dengan membudidayakan mencuci tangan baik dengan sabun atau handsanitizer sebelum melakukan aktivitas, memakai masker ketika berada dilingkungan kantor, dan menjaga jarak yang sesuai dan sejalan dengan peraturan ST/868/III/KEP./2020 tentang Antisipasi Virus Covid-19 (Spripim Polri, 2020) dapat mencegah ada nya kasus reaktif Covid-19.

\section{b. Saran}

Diperlukan pelaksanaan pengabdian kepada masyarakat ini dilakukan secara berkesinambungan, khusus nya melakukan edukasi membiasakan perilaku hidup bersih dan sehat sejak dini sebagai upaya menjaga diri dari segala penyakit yang ada dari masa kemasa.

\section{DAFTAR PUSTAKA}

Data Desa Kelurahan Pasirkamuning

Lembaga Penelitian dan Pengabdian Kepada Masyarakat, 2020, Panduan Pelaksaan Kuliah Kerja Nyata (KKN) Online Universitas Buana Perjuangan Karawang”.

Perhimpunan Dokter Paru Indonesia. (2020). Panduan Praktik Klinis: Pneumonia 2019-nCoV. PDPI: Jakarta

Prodeskel Bina Pemdes on: http://prodeskel.binapemdes.k e mendagri.go.id/mpublik/

Spripim Polri, 2020, Kumpulan Intisari Peraturan Dan Pedoman Corona Virus Disease 2019 (Covid-19), Jakarta Selatan, hal 20

WHO, 2020, WHO Director-General's remarks at the media briefing on 2019-nCov on 11 February 2020. Cited Feb 13rd 2020. Available on:https://www.who.int/dg/speec hes/detail/who-director-generalsremarks-at-the-media-briefingon-2019-ncov-on-11-february2020. (Feb 12th 2020)

Yuliana, 2020, Corona virus diseases (Covid-19), Wellness And Healthy Magazine, vol 2:1, hal 187-192 
Lia Fikayuniar ${ }^{1}$, Oviligiar Sugiharto ${ }^{2}$, Erliana Sari Ika Wahyuni ${ }^{3}$ Vol. 3 No 2, Agustus 2021

ISSN 2657-0203

e-ISSN 2686-0244 